\title{
SKRINING IN SILICO POTENSI SENYAWA ALLICIN DARI ALLIUM SATIVUM SEBAGAI ANTIPLASMODIUM
}

\section{IN SILICO SCREENING OF POTENTIAL ALLICIN COMPOUND FROM ALLIUM SATIVUM AS ANTIPLASMODIUM}

\author{
Fatmawaty $^{1}$, Muhammad Hanafi ${ }^{2}$, Rosmalena ${ }^{1}$ dan Vivitri Dewi Prasasty ${ }^{3}$ \\ ${ }^{1}$ Fakultas Kedokteran Universitas Indonesia, Jl. Salemba Raya 6 Jakarta 10430 \\ ${ }^{2}$ Pusat Penelitian Kimia, Lembaga Ilmu Pengetahuan Indonesia, Puspiptek, Serpong, 15314 \\ ${ }^{3}$ Fakultas Teknobiologi, Universitas Katolik Atma Jaya, Jl. Jenderal Sudirman 51, Jakarta 12930 \\ Email: fatmawatyyazid@yahoo.co.id
}

Diterima : 29 Oktober 2015, Revisi : 05 Nopember 2015, Disetujui : 02 Desember 2015

\begin{abstract}
ABSTRAK
Senyawa Allicin (2-propena-1-asam sulfinothioat S-2-propenil ester) diketahui memiliki potensi sebagai antiplasmodium secara in-vitro. Namun mekanisme aktivitas penghambatan Allicin terhadap plasmodium belum diketahui. Dalam penelitian ini, kami menentukan aktivitas Allicin secara in silico. Identifikasi sifat fisikokimia senyawa Allicin dan tiga turunan Allicin, yaitu Alc1, Alc2 dan Alc3 juga telah dilakukan. Selanjutnya, analisis drug-likeness dan adsorbsidistribusi-metabolisme-ekskresi (ADME) dilakukan terhadap senyawa Allicin dan turunannya untuk mendapatkan potensi senyawa tersebut sebagai kandidat obat. Dalam menentukan interaksi spesifik dilakukan analisis molecular docking senyawa Allicin dan turunannya terhadap protein target sistein protease (SP). Hasil molecular docking menunjukkan bahwa turunan Allicin, Alc2 (S-prop2-en-1-yl 3-methylbut-2-ene-1-sulfinothioate, $\mathrm{C}_{10} \mathrm{H}_{18} \mathrm{OS}_{2}$ ) memiliki potensi sebagai inhibitor yang lebih baik dibandingkan dengan Allicin, berdasarkan energi ikatan dan konstanta inhibisinya yang lebih rendah, dengan demikian Alc2 dapat dijadikan sebagai kandidat agen antiplasmodium.
\end{abstract}

Kata kunci: Allicin, turunan Allicin, drug likeness, ADME, molecular docking

\section{ABSTRACT}

Allicin compound (2-propene-1sulphinothioat acid S-2-propenyl ester) is known to have potential as antiplasmodium in vitro. However, the inhibitory activity mechanism of Allicin to plasmodium is still unknown. In this research, we determined the inhibitory activity of Allicin in silico. Identification of physicochemical properties of Allicin compound and two Allicin derivatives, Alcl, Alc2 and Ac2Alc3 were also conducted.. Furthermore, analysis of drug-likeness and adsorption-distribution-metabolism-excretion (ADME) were carried out on the Allicin compound and its derivatives to find the potential of these compounds as drug candidates. In determining the specific interaction, we utilized molecular docking analysis between Allicin and its derivatives against a protein target Cysteine Protease (SP). Molecular docking results showed that Allicin derivative, Alc2 (S-prop-2-en-1-yl 3-methylbut-2-ene-1sulfinothioate, $\mathrm{C}_{10} \mathrm{H}_{18} \mathrm{OS}_{2}$ ) has better potential as inhibitors than Allicin, based on the lower bond energies and the inhibition constants, thus Alc2 can be used as an antiplasmodium agent candidate.

Keywords: Allicin, Allicin derivatives, drug likeness, ADME, molecular docking

\section{PENDAHULUAN}

Malaria merupakan salah satu penyakit menular yang sangat serius di dunia. Setiap tahunnya, 300 hingga 500 juta kasus baru ditemukan dan terdapat sekitar 1,5 juta kasus kematian dari penyakit tersebut, diantaranya merupakan anak-anak yang mengalami kematian terbanyak $^{(1)}$. Lebih dari $40 \%$ populasi dunia tinggal dalam area endemik malaria beresiko tertular penyakit malaria ${ }^{(2)}$. Malaria secara langsung dapat menyebabkan anemia dan dapat menurunkan produktivitas kerja. Penyakit ini juga masih endemis di sebagian besar wilayah Indonesia. Menurut data DEPKES 2014, angka insidensi malaria di Indonesia pada tahun 2014 adalah 
1\%. Adapun lima provinsi dengan insidensi malaria tertinggi antara lain adalah Papua $(29,57 \%)$, Papua Barat $(20,85 \%)$, NTT $(12,81 \%)$, Maluku $(6,0$ $\%)$, dan Maluku Utara $(3,32 \%)^{(3)}$.

Infeksi pada penderita malaria terjadi ketika sporozoit Plasmodium masuk melalui kulit yang dibawa oleh nyamuk Anopheles. Sporozoit masuk ke dalam aliran darah dalam tubuh dan ditransport menuju organ hati, di mana sporozoit menyebarkan hepatosit, lalu mengalami diferensiasi dan membelah diri secara aseksual untuk memproduksi bentuk eksoeritrosit abnormal. Pada proses maturasi, eksoeritrosit mengalami perpecahan dan melepaskan merozoit yang akan menyerang eritrosit sehat, awal dari infeksi darah merah, yang bertanggung jawab pada gejala penyakit malaria. Insidensi malaria terus meningkat disebabkan beberapa faktor, diantaranya: rendahnya efektivitas vaksin dan resistensi parasit Plasmodium terhadap obat antimalaria yang tersedia, dengan demikian, eksplorasi alternatif obat baru dari tanaman obat tradisional yang efektif terus dikembangkan, baik sebagai agen propilaksis maupun pengobatan penyakit malaria $^{(4,5)}$.

Di antara target obat malaria yang terus dieksplorasi dalam pengembangan obat alternatif baru hingga kini yang paling berpotensi sebagai target obat adalah sistein protease Plasmodium. Sistein protease Plasmodium berperan penting dalam siklus hidup parasit malaria. Pada studi yang telah dilakukan sebelumnya, ditemukan bahwa protein sirkum sporozoit diproteolisis oleh sistein protease parasit sebagai tahap awal invasi penetrasi parasit ke dalam sel darah merah tubuh manusia, dan menyebabkan degradasi hemoglobin $^{(6,7)}$. Dengan demikian, inhibitor yang dapat menghambat sistein protease pada siklus hidup Plasmodium secara efektif dapat dijadikan kandidat obat yang baik sebagai agen pencegahan maupun pengobatan penyakit malaria ${ }^{(6)}$.

Berdasarkan beberapa penelitian sebelumnya ditemukan bahwa molecular docking mampu melakukan skrining pustaka senyawa dan melakukan kalkulasi ikatan terkuat antara senyawa bioaktif dengan protein target melalui berbagai fungsi skoring. Hal ini merupakan cara untuk mengeksplorasi dua molekul seperti kandidat obat dengan suatu enzim target, saling berikatan satu dengan yang lain. Molekul bioaktif atau ligan dapat berikatan pada suatu reseptor tertentu. Interaksi kompleks ligan-reseptor ini diidentifikasi oleh program docking dan afinitas ikatan mereka dievaluasi menggunakan simulasi energi bebas. Senyawa kimia bahan alam seperti chalcone dilaporkan mampu menghambat aspartat protease dan sistein protease plasmodium secara in silico menggunakan metode molecular docking. Sehingga aspartat protease dan sistein protease plasmodium menjadi target yang sangat atraktif untuk terapi antimalarial karena peran mereka dalam mendegradasi hemoglobin selama perkembangan parasite dalam sel eritrosit. Senyawa Sulfonamid dan turunannya juga dilaporkan memiliki aktivitas antimalaria. Strategi baru terus dikembangkan dengan mengadopsi berbagai teknik inhibisi terhadap parasit malaria $^{(9-12)}$.

Salah satu tanaman obat yang diketahui mampu menghambat parasit Plasmodium adalah bawang putih (Allium sativum). Allium sativum mengandung senyawa Allicin (2-propena-1-asam sulfinothioat S-2-propenil ester) yang merupakan molekul defensif bersifat aktif fisiologis dalam sel mikroba dan sel mamalia. Allicin dihasilkan dari Allicinin oleh enzim allinase dalam proses rusaknya jaringan pada umbi bawang putih akibat dipotong atau dicacah. Dalam dosis tertentu, Allicin dapat menghambat proliferasi bakteri, fungi dan sel kanker. Kemampuan Allicin menghambat 
proliferasi parasit Plasmodium diketahui secara spesifik menghambat sistein protease Plasmodium $^{(8)}$. Namun, mekanisme interaksi yang terjadi antara senyawa Allicin dengan target sistein protease masih belum diketahui. Tujuan dari penelitian ini adalah untuk menginvestigasi potensi dan mekanisme secara in-silico molekuler aktivitas inhibisi senyawa Allicin yang lebih baik dibandingkan obat malaria umum, artemisinin terhadap sistein protease Plasmodium. Adapun metode pendekatan yang dilakukan pada studi ini antara lain: analisa fisikokimia senyawa Allicin berdasarkan Quantitative StructureProperty Relationship, (QSPR), yaitu suatu metode perbandingan hubungan karakteristik struktur Allicin dengan turunannya untuk menentukan seberapa mirip kemampuan bioaktivitasnya berdasarkan kemiripan strukturnya; dan analisis molecular docking, untuk menentukan afinitas interaksi senyawa Allicin dan turunannya terhadap protein target SP dari plasmodium. Secara in silico, kedua metode analisis tersebut merupakan metode sinergi yang sangat baik dilakukan untuk skrining kandidat obat antiplasmodium.

\section{BAHAN DAN METODA}

\section{Bahan}

Struktur molekul tiga dimensi Allicin, derivat turunan Allicin (Alc1, Alc2 dan Alc3) dan Artemisinin sebagai molekul ligan inhibitor dan struktur tiga dimensi protein sistein protease Plasmodium sebagai target inhibitor.

\section{Peralatan}

Struktur tiga dimensi senyawa Allicin dan Artemisinin dibuat menggunakan program ChemDraw versi 7.0. Uji senyawa Allicin berdasarkan Quantitative Structure - Property
Relationship, $(Q S P R)$ dilakukan secara insilico dengan web-based application. Pengujian interaksi molekul ligan dengan protein menggunakan molecular docking dilakukan dengan program Autodock Vina ${ }^{(13-14)}$.

\section{Metoda Preparasi Struktur Protein dan Ligan}

Struktur 3D protein sistein protease Plasmodium falciparum diperoleh dari PDB (Kode ID = 1YVB), dimana dilakukan delesi pada ligan yang terikat dalam struktur kristal protein dan molekul air menggunakan program Chimera 1.8.1. Struktur protein tanpa ligan tersebut di evaluasi koordinat asam amino penyusunnya menggunakan Kobamin, dan divalidasi menggunakan PROCHECK ${ }^{(15)}$. Struktur 3D senyawa Allicin, turunan Allicin dan Artemisinin sebagai ligan dibuat dengan program ChemDraw Ultra 7.0 untuk digunakan dalam analisis QSAR dan molecular docking. Energi konformasi ligan diminimasi menggunakan MMFF94 force field. Semua struktur 3D protein SP dan ligan akhir disimpan dalam format $\mathrm{pdb}$, yaitu format struktur 3D dengan koordinat atom standar suatu biomolekul (Gambar 1).

\section{Metoda Analisis Senyawa Allicin berdasarkan Quantitative Structure- Property Relationship, (QSPR)}

Struktur 3D Allicin dianalisis berdasarkan sifat fisikokimia menggunakan program Molsoft DrugLikeness. Penentuan sifat-sifat fisikokimia ini penting dalam pengembangan kandidat obat di setiap tahap mulai dari studi perancangan hingga uji pre-klinis. Sifatsifat obat seperti daya penyerapan, distribusi, metabolism dan ekskresi (ADME) harus dipertimbangkan dalam pengembangan obat. Identifikasi ADME pada tahap awal akan membawa senyawa menuju penapisan obat. Sifat-sifat yang 
tidak di inginkan pada senyawa akan menyebabkan kegagalan dalam pengembangan obat. Prediksi sifat ADME senyawa kandidat obat menggunakan program ACD/I-lab ${ }^{(16)}$ dan FAF-Drugs $3^{(17)}$, Pada penelitian ini, senyawa Allicin dan turunannya dianalisis sifat ADME berdasarkan bioavailabilitas secara oral, volume distribusi, penyerapan ke saluran pencernaan, dan evaluasi protein ikat plasma (Gambar 1).

\section{Metoda Molecular Docking Senyawa Kompleks Allicin-Sistein Protease}

Analisis molecular docking dilakukan program Autodock Vina (Vina, The Scripps Institute) ${ }^{(13)}$. AutodockTools digunakan untuk preparasi protein seperti pengaturan jumlah muatan elektron dan penyusunan senyawa hidrogen polar.Ligan dipreparasi memiliki sudut fleksibel. Lalu protein dan ligan disimpan dalam format pdbqt, yaitu suatu format dengan ekstensi spesifik yang menyimpan koordinat atom, muatan parsial dan tipe atom yang dikenali secara spesifik oleh program molecular docking Autodock Vina (Gambar 2). Penentuan molecular docking spesifik antara sistein protease dan Allicin menghasilkan energi ikatan yang melibatkan total energi intermolekul (kkal/mol) meliputi energi ikatan hidrogen, energi Van der Waals, energi disolvasi dan energi elektrostatik.
Ligan (format dalam bentuk pdb)

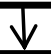

Desain struktur Allicin, Alc1, Alc2, Alc3, Artemisinin dengan program Chemdraw

Ultra 7.0

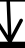

Minimasi Energi menggunakan MMFF94 forcefield $\downarrow$

Uji drug-likeness dengan program Molsoft

$\downarrow$

Uji ADME dengan program ACD/Lab dan FAF-Drug3
Protein target (format dalam bentuk pdb)

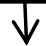

Struktur 3D Sistein Protease Plasmodium

falciparum, ID code: $1 \mathrm{YVB}$ diunduh dari www.pdb.org

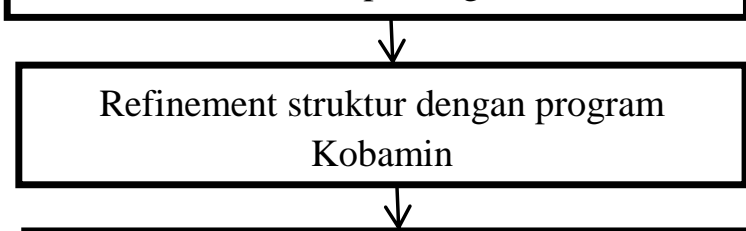

Validasi struktur dengan program PROCHECK

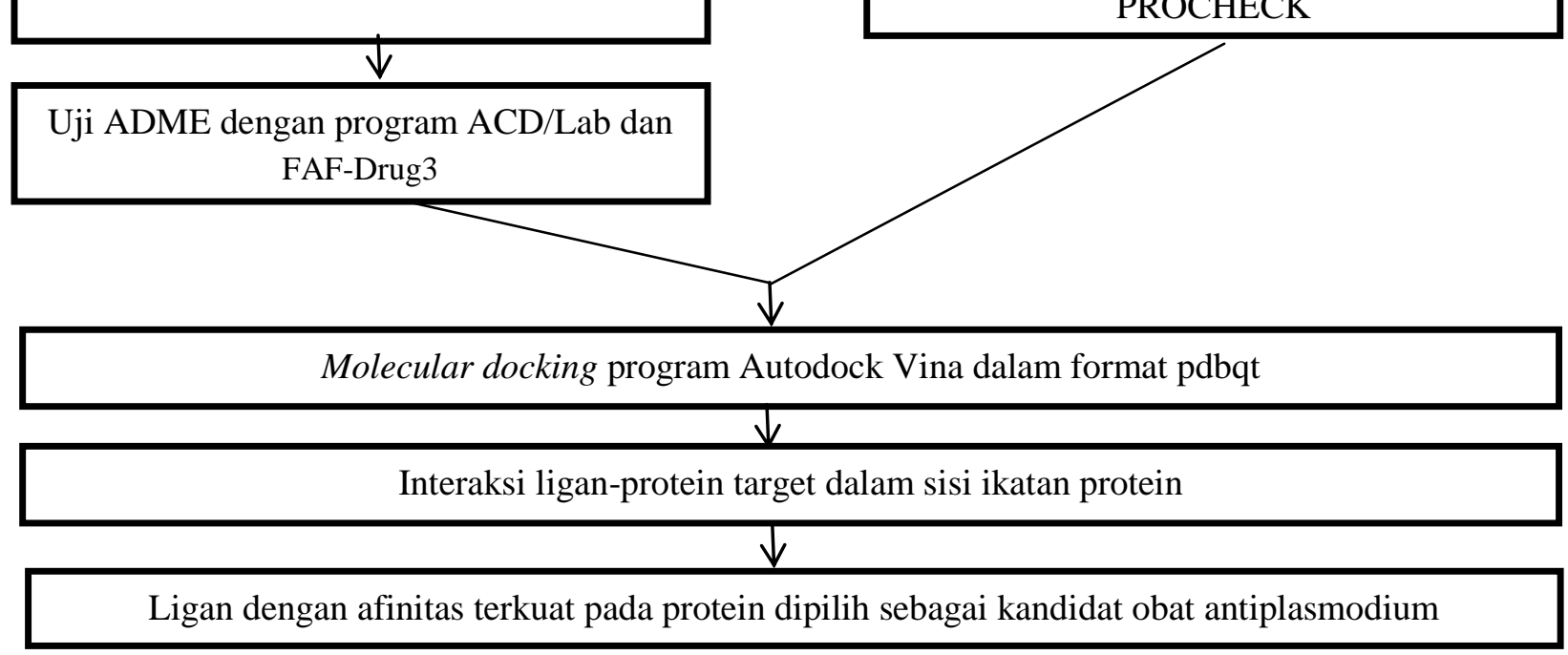

Gambar 1. Skema Diagram alir metode preparasi hingga analisis interaksi molekul 

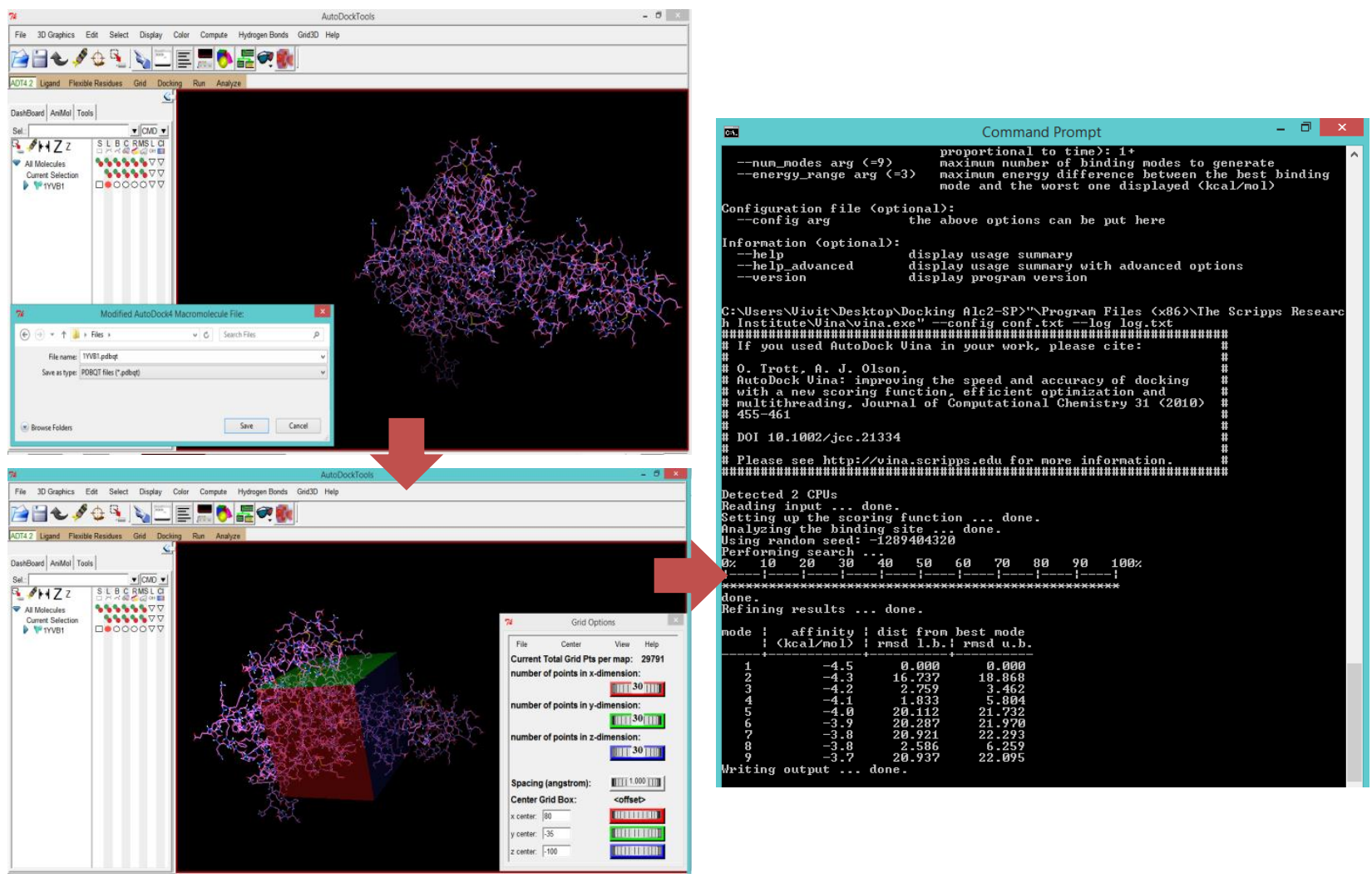

Gambar 2. Skema simulasi interaksi ligan-reseptor dengan program molecular docking Autodock Vina dengan urutan preparasi ligand dan reseptor dalam format pdbqt $\rightarrow$ menentukan volume gridbox reseptor sebagai lokasi ikatan dengan ligan $\rightarrow$ mengoperasikan program docking

\section{HASIL DAN PEMBAHASAN}

\section{Analisis senyawa Allicin berdasarkan Quantitative Relationship, (QSPR) \\ Structure-Activity}

Struktur senyawa tiga dimensi Allicin dan turunan Allicin telah dirancang, dimana perbedaan struktur antara Allicin dengan turunannya dilakukan berdasarkan substitusi gugus samping propena dengan suatu gugus hidrofobik alifatik dimetil: Alc1 Alc2 dan Alc3. Substitusi ini dilakukan untuk menggali potensi turunan Allicin yang lebih baik sebagai antiplasmodium dibandingkan dengan Allicin (Gambar 3) dan Artemisinin. Analisis senyawa Allicin dan turunannya dilakukan berdasarkan penentuan sifat fisikokimia dan sifat $d r u g-$ likeness, di mana senyawa Artemisinin digunakan sebagai senyawa pembanding (Tabel 1 dan Tabel 2).

Berdasarkan hasil analisis fisikokimia Allicin, turunan Allicin dan Artemisinin, diperoleh variasi sifat intrinsik yang dimiliki keempat senyawa tersebut, dimana sifat keempat struktur tidak memiliki donor proton, variasi akseptor proton berada pada kisaran $3-5$ buah, variasi bobot molekul berada pada rentang 160 - 285, rotasi ikatan sebanyak 5-9 buah hanya ditemukan pada senyawa Allicin dan turunannya namun tidak ditemukan sama sekali pada senyawa Artemisinin. Rentang indeks refraktori berada di antara 1,533 - 1,567, rentang densitas keempat senyawa berada pada $1,102-1,240 \mathrm{~g} / \mathrm{cm}^{3}$, dan tegangan permukaan berada pada rentang 43,5 47,3 dyne/cm. 


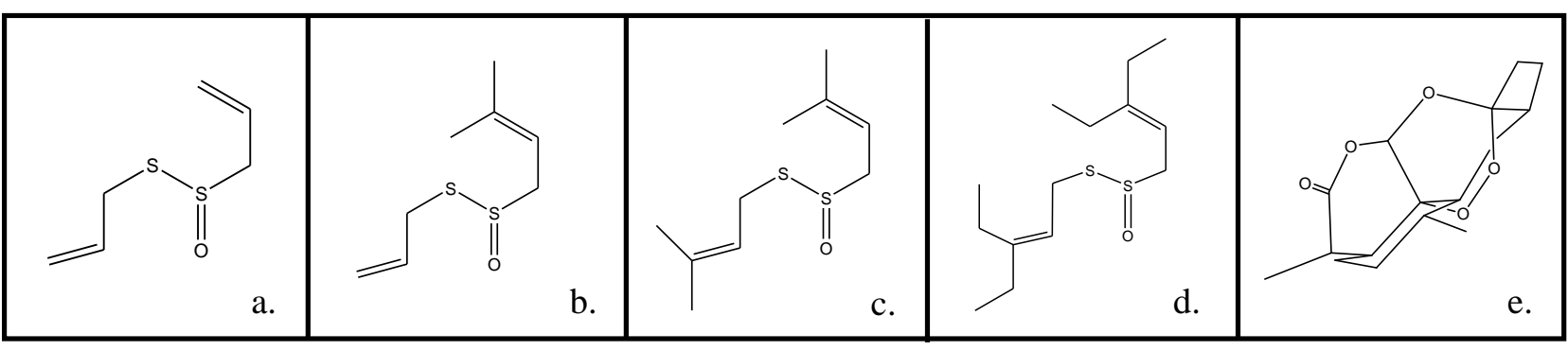

Gambar 3. Struktur senyawa inhibitor: a. Allicin, b. turunan-1 Allicin (Alc1), c. turunan-2 Allicin (Alc2), d. turunan-3 Allicin (Alc3), e. Artemisinin

Tabel 1. Sifat fisiko-kimia molekul Allicin, turunan Allicin dan obat parasit malaria komersil

\begin{tabular}{cccccccc}
\hline $\begin{array}{c}\text { Nama } \\
\text { molekul }\end{array}$ & $\begin{array}{c}\text { Donor } \\
\text { HB* }\end{array}$ & $\begin{array}{c}\text { Akseptor } \\
\text { HB* }\end{array}$ & $\begin{array}{c}\text { Bobot } \\
\text { molekul }\end{array}$ & $\begin{array}{c}\text { Rotasi } \\
\text { ikatan }\end{array}$ & $\begin{array}{c}\text { Indeks } \\
\text { Refraktori }\end{array}$ & $\begin{array}{c}\text { Densitas } \\
\left(\mathbf{g} / \mathbf{c m}^{\mathbf{3}}\right)\end{array}$ & $\begin{array}{c}\text { Tegangan } \\
\text { permukaan } \\
(\mathbf{d y n e} / \mathbf{c m})\end{array}$ \\
\hline Allicin & 0 & 3 & 162,02 & 5 & 1,567 & 1,148 & 47,30 \\
\hline Alc1 & 0 & 3 & 190,05 & 5 & 1,557 & 1,102 & 43,90 \\
\hline Alc2 & 0 & 1 & 218,38 & 5 & 1,550 & 1,070 & 41,70 \\
\hline Alc3 & 0 & 3 & 274,49 & 9 & 1,531 & 1,016 & 39,60 \\
\hline Artemisinin & 0 & 5 & 282,15 & 0 & 1,533 & 1,240 & 43,50 \\
\hline *HB = Hydrogen bond & & & & & & &
\end{tabular}

Tabel 2. Sifat drug likeness molekul Allicin, turunan Allicin dan obat parasit malaria komersil

\begin{tabular}{ccccccc}
\hline $\begin{array}{c}\text { Nama } \\
\text { molekul }\end{array}$ & $\begin{array}{c}\text { Nilai Drug } \\
\text { Likeness** }\end{array}$ & Log P** & $\begin{array}{c}\text { Kelarutan } \\
(\mathbf{m g} / \mathbf{L})^{*}\end{array}$ & $\boldsymbol{T P S A}^{* * *}$ & $\begin{array}{c}\text { Jumlah pusat } \\
\text { stereo** }^{* *}\end{array}$ & $\begin{array}{c}\text { Penyimpangan } \\
\text { Hukum } \\
\text { Lipinski** }\end{array}$ \\
\hline Allicin & $-0,84$ & 2,40 & 3342,58 & 61,58 & 0 & 0 \\
\hline Alc1 & $-1,03$ & 3,32 & 475,94 & 61,58 & 0 & 0 \\
\hline Alc2 & $-0,99$ & 4,23 & 13645,12 & 61,58 & 0 & 0 \\
\hline Alc3 & $-0,95$ & 4,76 & 5303,08 & 61,58 & 0 & 0 \\
\hline Artemisinin & $-1,30$ & 2.60 & 1606,48 & 53,99 & 7 & 0 \\
\hline$* *$ Molsoft Drug-Likeness & & & & & \\
$* * * F A F-D r u g s 3$ & & & & &
\end{tabular}

Hasil penentuan sifat drug likeness memiliki variasi nilai antara -1,30 hingga 0,84. Nilai Log P keempat senyawa berada pada rentang $1,85-4,76$, dimana nilai $\log$ $\mathrm{P}$ keempat senyawa sudah baik berdasarkan koefisien partisi oktanol/air. Kelarutan keempat senyawa berada pada rentang 475,94 - 13645,12 mg/L di mana senyawa Alc2 memiliki tingkat kelarutan yang paling baik dibanding ketiga senyawa lainnya, dan senyawa turunan Alc1 memiliki kelarutan paling rendah. Nilai
TPSA (Topological Polar Surface Area) keempat senyawa berada pada rentang 53,99 - 61,58 dimana keempat senyawa tersebut memiliki nilai TPSA yang sudah baik karena memiliki nilai TPSA sesuai standar yaitu kurang dari $150^{(18)}$. Berdasarkan hasil analisa drug likeness, dapat dinyatakan bahwa keempat molekul sudah memenuhi semua kriteria Lima aturan Lipinski ${ }^{(19,20)}$ dimana tidak ditemukan penyimpangan sifat $d r u g$ likeness pada keempat senyawa tersebut. 
Tabel 3. Sifat ADME molekul ligan inhibitor parasit malaria

\begin{tabular}{cccccc}
\hline $\begin{array}{c}\text { Nama } \\
\text { molekul }\end{array}$ & $\begin{array}{c}\text { Bioavailabilitas } \\
\text { Oral }\end{array}$ & $\begin{array}{c}\text { Volume } \\
\text { distribusi } \\
\text { (L/kg) }\end{array}$ & $\begin{array}{c}\text { \% Absorbsi } \\
\text { jejunum } \\
\text { maksimum }\end{array}$ & $\begin{array}{c}\text { Tipe } \\
\text { absorbsi }\end{array}$ & $\begin{array}{c}\text { \% Protein ikat } \\
\text { plasma }\end{array}$ \\
\hline Allicin & Baik & 1,64 & 100 & Transeluler & 83,54 \\
\hline Alc1 & Baik & 2,02 & 100 & Transeluler & 83,98 \\
\hline Alc2 & Baik & 2,30 & 100 & Transeluler & 82,26 \\
\hline Alc3 & Baik & 3,90 & 100 & Transeluler & 91,77 \\
\hline Artemisinin & Baik & 1,39 & 100 & Transeluler & 82,15 \\
\hline
\end{tabular}

Pada analisa lebih lanjut, penentuan sifat adsorbsi-distribusi-metabolismeekskresi (ADME) kandidat obat dalam tubuh manusia sangat penting dilakukan $^{(21)}$. Pada penelitian ini didapatkan hasil penentuan bioavailabilitas oral yang baik dan volume distribusi pada rentang 1,09-3,90 L/kg dari keempat senyawa tersebut. Persentase absorbsi jejunum maksimum keempat senyawa tersebut juga ditemukan mencapai $100 \%$ dengan tipe absorbsi melalui jalur transeluler. Persentase protein ikat plasma keempat senyawa pada rentang 82,15 $91,77 \%$, dimana senyawa deriva Alc2 memiliki fraksi terikat pada protein dalam plasma darah paling kecil dibandingkan dengan ketiga senyawa lain. Hal ini mengindikasikan bahwa sebagian besar fraksi senyawa Alc2 tidak terikat dalam protein plasma darah akan terbawa ke dalam sistem metabolisme tubuh sampai tahap eksresi, maka tingkat obat terakumulasi dalam tubuh menjadi lebih kecil dibandingkan dengan ketiga senyawa lainnya, sehingga senyawa Alc2 dinilai memiliki sifat ADME yang paling baik, karena memiliki tingkat resiko toksisitas paling rendah dalam tubuh.

\section{Molecular Docking Senyawa Kompleks Allicin-Sistein Protease}

Dalam menentukan interaksi senyawa Allicin dan turunan Allicin, kami menggunakan analisa molecular docking untuk menentukan interaksi spesifik antar ligan, dalam hal ini senyawa Allicin beserta turunannya dengan protein target sistein protease.

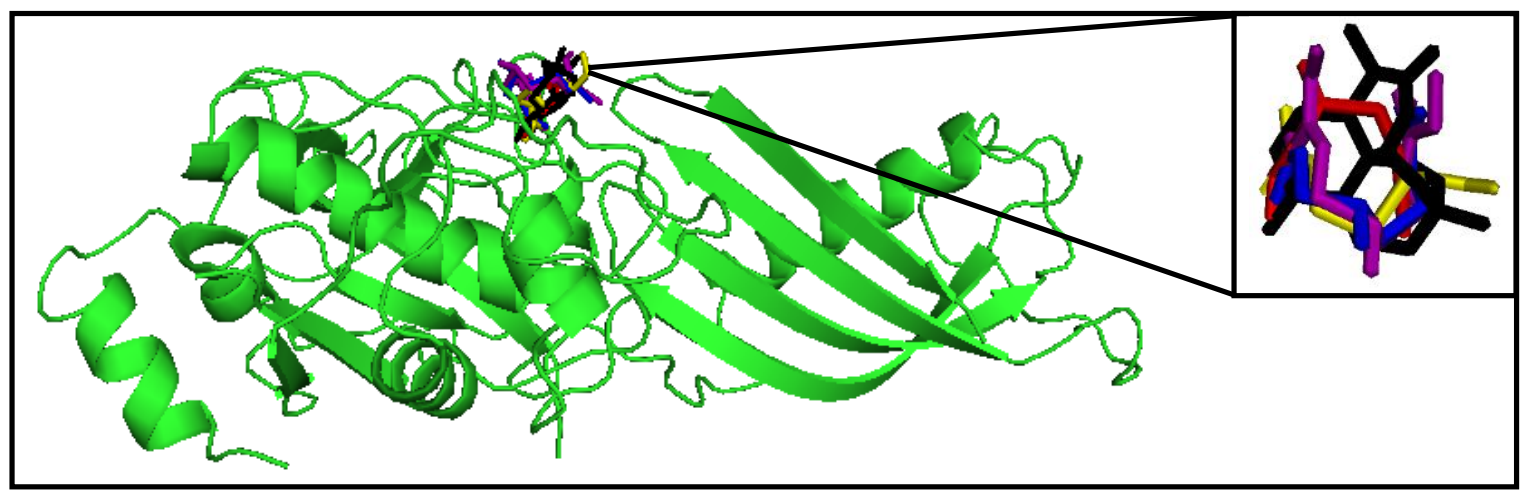

Gambar 4. Interaksi molecular docking protein SP dengan ligan Allicin (merah), Alc1 (kuning), Alc2 (biru), Alc3 (ungu) dan Artemisinin (hitam)

Berdasarkan hasil docking diperoleh bahwa, senyawa Allicin (warna merah), Alc1 (warna kuning), Alc2 (warna biru),
Alc3 (warna ungu) dan Artemisinin (warna hitam) memiliki sisi ikatan yang sama pada sistein protease (Gambar 4). 


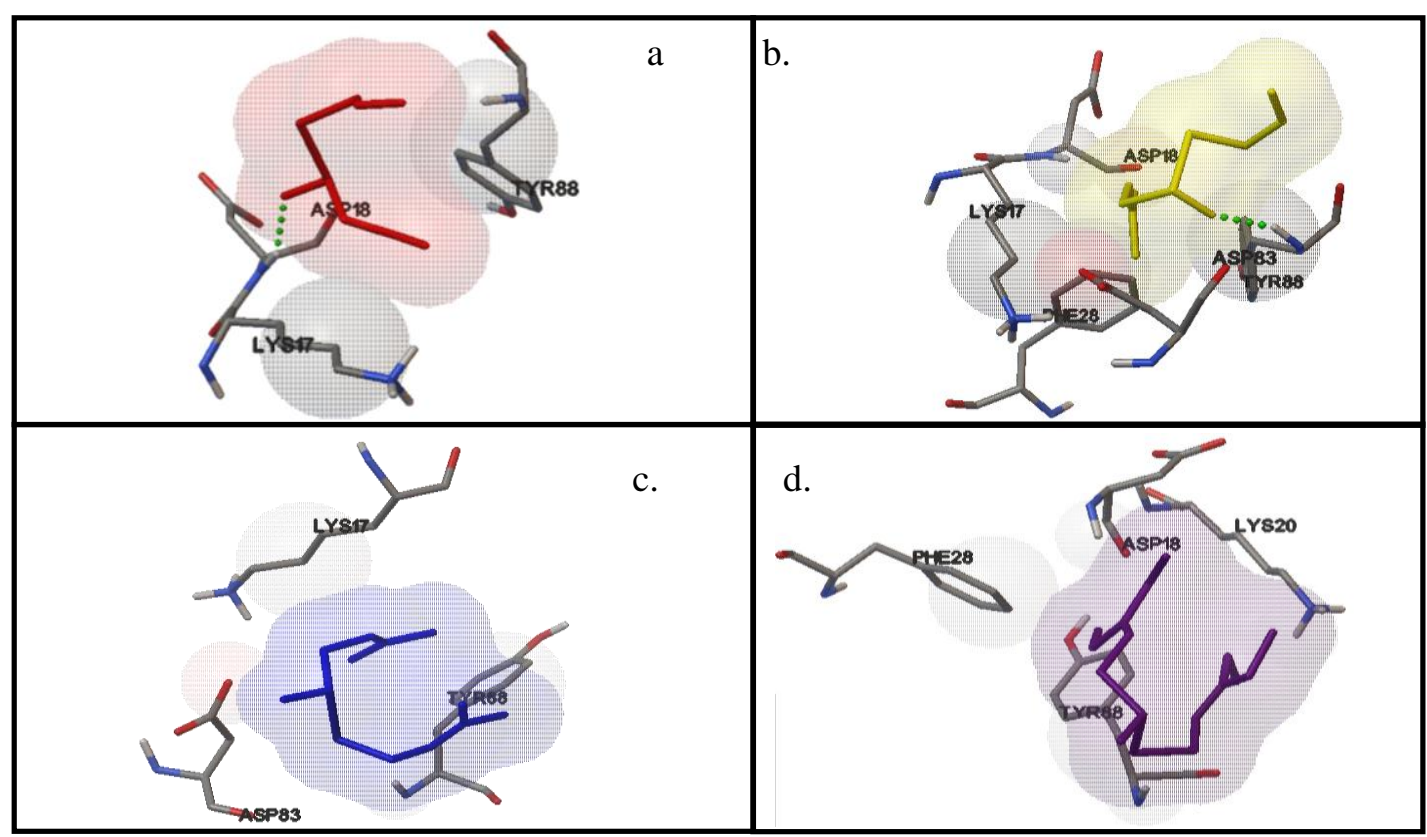

Gambar 5. Interaksi molecular docking: a) Interaksi residu SP-Allicin,, b) Interaksi residu SP-Alc1 c) Interaksi residu SP-Alc2, d) Interaksi residu SP-Alc3

Tabel 4. Ringkasan Hasil Analisis Molecular Docking

\begin{tabular}{ccccc}
\hline $\begin{array}{c}\text { Nama } \\
\text { molekul }\end{array}$ & $\begin{array}{c}\text { Energi ikat } \\
\text { (kkal/mol) }\end{array}$ & $\begin{array}{c}\text { Residu asam amino yang terlibat } \\
\text { dalam interaksi kompleks protein- } \\
\text { ligan }\end{array}$ & $\begin{array}{c}\text { i ikatan } \\
\text { hidrogen }\end{array}$ & $\begin{array}{c}\text { Nilai Ki } \\
\text { (nM) }\end{array}$ \\
\hline Allicin & $-3,2$ & Asp18, Lys17, Tyr88 & 1 & $4,47 \times 10^{-1}$ \\
\hline Alc1 & $-3,8$ & Lys17, Asp18, Phe28, Asp83, Tyr88 & 1 & $1,63 \times 10^{-12}$ \\
\hline Alc2 & $-4,1$ & Lys17, Asp83, Tyr88 & 0 & $6,93 \times 10^{-12}$ \\
\hline Alc3 & $-3,8$ & Asp18, Lys20, Phe28, Tyr88 & 0 & $1,63 \times 10^{-12}$ \\
\hline $\begin{array}{c}\text { Artemisinin } \\
\text { (Kontrol) }\end{array}$ & $-6,9$ & $\begin{array}{c}\text { Lys17, Asp18, Lys20, Phe28, Glu50, } \\
\text { Asp83, Tyr88 }\end{array}$ & 1 & $8,63 \times 10^{-15}$ \\
\hline
\end{tabular}

Interaksi senyawa Allicin, turunan Alc1 dan Artemisinin dengan residu asam amino tertentu pada sistein protease distabilkan oleh satu ikatan hidrogen. Ikatan hidrogen ini terbentuk antara gugus amina dari rantai samping asam amino Asparagin-18 dengan molekul hidrogen dari Allicin, turunan Alc1 dan Artemisinin. Senyawa turunan Alc2 dan Alc3 hanya mengalami interaksi hidrofobik dan Van der Waals dengan residu asam amino spesifik dari sistein protease (Gambar 5). Berdasarkan hasil interaksi docking, dimana nilai energi ikat dan konstanta inhibisi diperoleh bahwa senyawa Alc2 memiliki kemampuan inhibisi paling tinggi dibandingkan dengan senyawa Allicin, Alc1 dan Alc3, namun masih lebih rendah dibandingkan dengan obat antimalaria komersil Artemisinin (Tabel 4). .Hasil penelitian in silico ini menunjukkan bahwa senyawa turunan Alc2 dapat dijadikan sebagai kandidat agen antiplasmodium. Penelitian ini membutuhkan tahap uji lanjut in vitro maupun in vivo sebagai langkah validasi aktivitas senyawa Alc2 dalam sel hidup. 


\section{KESIMPULAN}

Senyawa Allicin dan turunannya telah berhasil diuji secara in silico, dan senyawa Allicin memiliki sifat drug likeness dan sifat ADME yang baik sebagai kandidat agen antiplasmodium. Aktivitas spesifik senyawa Allicin dan turunannya menunjukkan aktivitas inhibisi terhadap protein target sistein protease, di mana senyawa turunan Alc2 (Energi ikat = $-4,1 \mathrm{kkal} / \mathrm{mol} ; \mathrm{Ki}=6,93 \times 10^{-12} \mathrm{nM}$ ) memiliki aktivitas inhibisi paling baik dibandingkan dengan senyawa Allicin (energi ikat $=-3,2 \mathrm{kkal} / \mathrm{mol} ; \mathrm{Ki}=4,47 \times 10^{-}$ $12 \mathrm{nM}$ ), Alc1 (Energi ikat = -3,8 kkal $/ \mathrm{mol}$; $\mathrm{Ki}=1,63 \times 10^{-12} \mathrm{nM}$ ) dan Alc3 (Energi ikat $\left.=-3,8 \mathrm{kkal} / \mathrm{mol} ; \mathrm{Ki}=1,63 \times 10^{-12} \mathrm{nM}\right)$. Dengan demikian, modifikasi lebih lanjut senyawa turunan Allicin masih sangat mungkin dilakukan untuk mendapatkan senyawa dengan aktivitas inhibisi parasit malaria yang sama bahkan lebih baik daripada obat Artemisinin.

\section{DAFTAR PUSTAKA}

1. L.F. Rocha e Silva, K.L. Nogueira, A.C. Pinto, A.M. Katzin, R.A. Sussmann. In vivo antimalarial activity and mechanisms of action of 4nerolidylcatechol derivatives. Antimicrob Agents Chemother. 59: 3271-3280.(2015)

2. A.C. Aguiar, M. Santos Rde, F.J. Figueiredo, W.A. Cortopassi, A.S. Pimentel. Antimalarial activity and mechanisms of action of two novel 4aminoquinolines against chloroquineresistant parasites. PLoS One. 7: e37259.(2012)

3. Kementerian Kesehatan RI. 2011, Epidemiologi Malaria di Indonesia. Buletin Jendela Data dan Informasi Kesehatan. ISSN 2088 - 270X. Volume 1:1-39. www.depkes.go.id/download.php\%3Ff
ile\%3Ddownload/pusdatin/buletin/bule tin-

malaria.pdf $+\& c d=1 \& h l=e n \& c t=c \operatorname{lnk} \&$ $\mathrm{gl}=\mathrm{id}$, accessed on Sept 28, 2015.

4. A.K. Talley, S.A. Healy, O.C. Finney, S.C. Murphy, J. Kublin. Safety and comparability of controlled human Plasmodium falciparum infection by mosquito bite in malaria-naive subjects at a new facility for sporozoite challenge. PLoS One. 9: e109654.(2014)

5. V. Risco-Castillo, O.Son, J.F. Franetich, E. Rubinstein, D. Mazier. Plasmodium sporozoite entry pathways during malaria liver infection. Biol Aujourdhui. 207: 219-229.(2013)

6. K.E. Boysen and K. Matuschewski. Inhibitor of cysteine proteases is critical for motility and infectivity of Plasmodium sporozoites. MBio. 4: e00874-00813.(2013)

7. Y. Pei, J.L. Miller, S.E. Lindner, A.M. Vaughan, M. Torii. Plasmodium yoelii inhibitor of cysteine proteases is exported to exomembrane structures and interacts with yoelipain-2 during asexual blood-stage development. Cell Microbiol. 15: 1508-1526.(2013)

8. A. Coppi, M. Cabinian, D. Mirelman, P. Sinnis. Antimalarial activity of allicin, a biologically active compound from garlic cloves. Antimicrob Agents Chemother. 50: 1731-1737.(2006)

9. N. Yadav, S.K. Dixit, A. Bhattacharya, L.C. Mishra, M. Sharma, S.K. Awasthi, V.K. Bhasin, Antimalarial activity of newly synthesized chalcone derivatives in vitro. Chem. Biol. Drug Des. 80: 340-347.(2012)

10. N. Tadigoppula, V. Korthikunta, S. Gupta, P. Kancharla, T. Khaliq, A. Soni, R.K. Srivastava, K. Srivastava, S.K. Puri, K.S. Raju. Synthesis and insight into the structure-activity relationships of chalcones as 
antimalarial agents. J. Med. Chem. 56: 31-45.(2013)

11. P.A. Moura. J.B. Dame, D.A. Fidock. Role of plasmodium falciparum digestive vacuole plasmepsins in the specificity and antimalarial mode of action of cysteine and aspartic protease inhibitors. Antimicrob. Agents Chemother. 53: 4968-4978.(2009)

12. V.K. Agrawal, R. Srivastava, P.V. Khadikar. Qsar studies on some antimalarial sulfonamides. Bioorg. Med. Chem. 9: 3287-3293.(2001)

13. V.Y. Tanchuk, V.O. Tanin, A.I. Vovk, G. Poda. A New Scoring Function for Molecular Docking Based on AutoDock and AutoDock Vina. Curr Drug Discov Technol.(2015)

14. O.Trott andA.J.Olson. AutoDock Vina: improving the speed and accuracy of docking with a new scoring function, efficient optimization, and multithreading. J Comput Chem. 31: 455-461.(2010)

15. R.A. Laskowski, J.A. Rullmannn, M.W. MacArthur, R. Kaptein, J.M. Thornton. AQUA and PROCHECKNMR: programs for checking the quality of protein structures solved by NMR. $J$ Biomol NMR. 8: 477486.(1996)

16. ACD/Structure Elucidator, version 15.01, Advanced Chemistry Development, Inc., Toronto, ON, Canada, www.acdlabs.com, accessed on Sept 28, 2015.

17. D. Lagorce, O. Sperandio, J.B. Baell, M.A. Miteva, B.O. Villoutreix. FAFDrugs3: a web server for compound property calculation and chemical library design. Nucleic Acids Res. 43: W200-207.(2015)

18. S. Shityakov, W. Neuhaus, T. Dandekar, C. Förster. Analysing molecular polar surface descriptors to predict blood-brain barrier permeation.
Int. J. Comput. Biol. Drug Des. 6: 146156.(2013)

19. C.A. Lipinski, F. Lombardo, B.W. Dominy, P.J. Feeney. Experimental and computational approaches to estimate solubility and permeability in drug discovery and development settings. Adv. Drug Deliv. Rev. 46: $3-$ 26.(2001)

20. C.A. Lipinski. Lead- and drug-like compounds: the rule-of-five revolution. Drug Discovery Today: Technologies 1: 337-341.(2004)

21. G. Borbely, M. Huszar, A.Varga, K. Futosi, A. Mocsai. Optimization of important early $\mathrm{ADME}(\mathrm{T})$ parameters of NADPH oxidase-4 inhibitor molecules. Med Chem. 8: 174181.(2012) 